\title{
OPEN VERSUS CLOSED TREATMENT OF SUBCONDYLE MANDIBLE FRACTURE: AN EVIDENCE-BASED CASE REPORT
}

\author{
Kristaninta Bangun ${ }^{*}$, Irinawati Nangingtuari², Andria Olivia ${ }^{3}$, Muhammad Iqbal Maulana ${ }^{4}$
}

1. Universitas Indonesia, Department of Surgery, Division of Plastic Reconstructive and Aesthetic Surgery, RSUPN Cipto Mangunkusumo, Jakarta, Indonesia

Plastic Reconstruction and Aesthetic Surgeon, Eka Hospital BSD

General Practitioner, Eka Hospital BSD

General Practitioner, National General Hospital Cipto Mangunkusumo

\section{ABSTRACT}

Background : Mandibular subcondyle fractures are accounted for 25\%-35\% of all mandible fractures. Closed treatment has been the preferred treatment for several years because it's relatively easier and non invasive but the complications that may arise are varied. Open reduction was one of the options that is considered to reduce complications. This study examines whether open reduction was a better choice than closed reduction in the management of mandible subcondyle fracture with parameter outcomes are complications, facial nerve injury, pain, and mouth occlusion.

Method : A literature study was conducted from two databases: PubMed and Journal of Cranio-Maxillo-Facial Surgery (JOMS) with predefined keywords and references from 23-28 January 2018. The search was conducted with mandible subcondyle fracture, open reduction, and closed reduction. The search has been limited only for the last 5 years and limited to meta-analysis and systematic review. From the search, there were three articles used based on inclusion criteria in this case review.

Result : The reviewed articles showed that open reduction provides better results than closed reduction, although open reduction result in complications of facial injuries and facial nerve weakness, but the complications were transient and tolerable.

Conclusion: Based on existing clinical evidence, open reduction was the preferred management rather than closed. reduction due to better outcome and fewer complication.

Keywords: subcondylar mandibular fracture, closed treatment, ORIF, open treatment

Latar Belakang: Fraktur subkondilar mandibula adalah salah satu fraktur yang paling sering terjadi pada wajah. Metode yang paling banyak digunakan untuk mengatasinya adalah secara konservatif karena relatif lebih mudah dan tidak invasif. Reduksi terbuka merupakan salah satu metode yang dianggap dapat mengurangi komplikasi. Studi ini menguji apakah reduksi terbuka adalah pilihan yang lebih baik daripada reduksi tertutup pada manajemen fraktur subkondilar mandibula yang dihubungkan dengan hasil klinis.

Metodologi: Studi literature di lakukan dari dua database: PubMed dan JOMS dengan kata kunci dan referensi yang telah ditetapkan pada 23-28 Januari 2018. Pencarian di lakukan dengan mandible subcondyle fracture, open reduction, and closed reduction selama 5 tahun terakhir dan hanya untuk meta analisis dan systematic review. Dari hasil pencarian, terdapat 3 artikel yang digunakan pada penelitian ini.

Hasil: Meta analisis dan systematic review dari 3 literatur menunjukan bahwa reduksi terbuka memberikan hasil lebih baik dari reduksi tertutup, walaupun reduksi terbuka menyebabkan komplikasi kerusakan wajah dan saraf wajah melemah.

Kesimpulan: Berdasarkan bukti klinis yang ada, reduksi terbuka merupakan manajemen yang lebih di pilih daripada reduksi tertutup dalam perspektif hasil subjektif dan objektif yang lebih baik dengan komplikasi yang sedikit.

Keywords: subcondylar mandibular fracture, closed treatment, ORIF, open treatment 


\section{CASE ILLUSTRATION}

Mr. Y, 25 years old came with chief complaint of pain in the right upper jaw for one day before entering the hospital. The pain was persistent. This was caused by car accident. The patient wore a seatbelt and his face hit the car air bag. After the incident, the patient was fully conscious, had no headache, no nausea and no vomiting. The patient was immediately taken to the nearest hospital with a collar neck and was treated with analgesic, but wasn't improving. In addition, the patient also complained that he couldn't close his mouth properly and had difficulties in eating.

From physical examination, the patient's consciousness was compos mentis, the blood pressure was $120 / 70 \mathrm{mmHg}$, the pulse was 80 times per minute with enough and regular contents, the respiratory rate was 18 times per minute, asymmetrical on the face, swelling in the right and left preauriculer with malocclusion was obtained bilaterally and limited mouth movement, the patient could open the mouth for maximum of 2 fingers.

A 3D Computer Tomography(CT) scan was performed to the patient, showed left mandible subcondylar fracture and right mandible angle fracture with temporomandibular joint dysfunction position within normal limit in both the right and left areas.

Patient was advised to be hospitalized and nasogastric tube (NGT) was placed, the liquid diet via nasogastric tube that was given were milk and blended juice, the medication given to the patient was a ketorolac injection $30 \mathrm{mg}$ per 12-hour, patient was planned to have Open Reduction and Internal Fixation for the mandibular fractures.

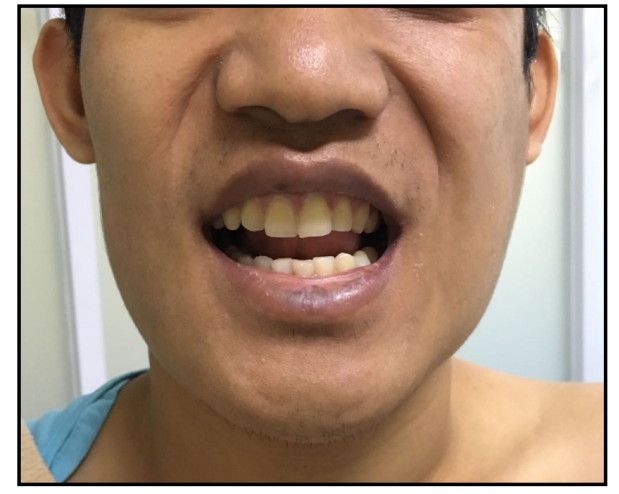

Figure 1. Open bite malocclusion (patient could not close the mouth completely)
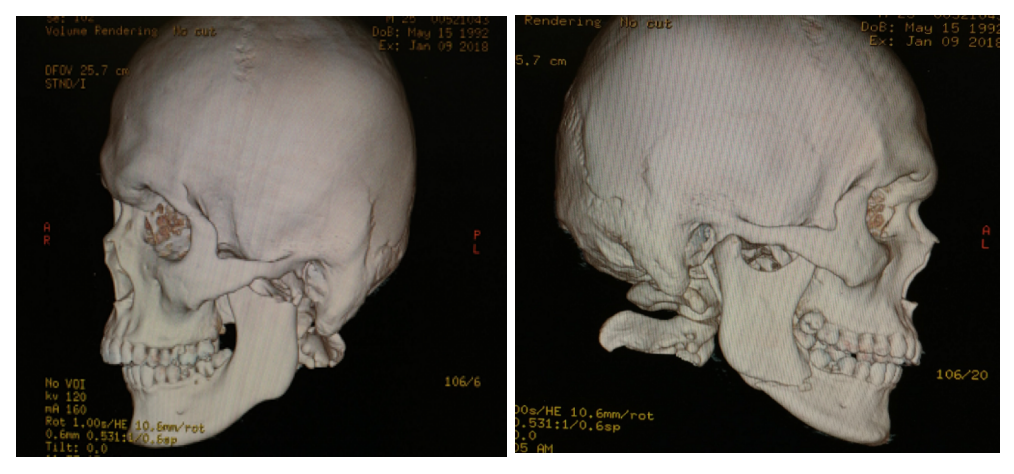

Figure 2a. 3D CT scan from lateral view with left mandible subcondylar fracture and right mandible angle fracture with TMJ position in is within normal limit both the right and left

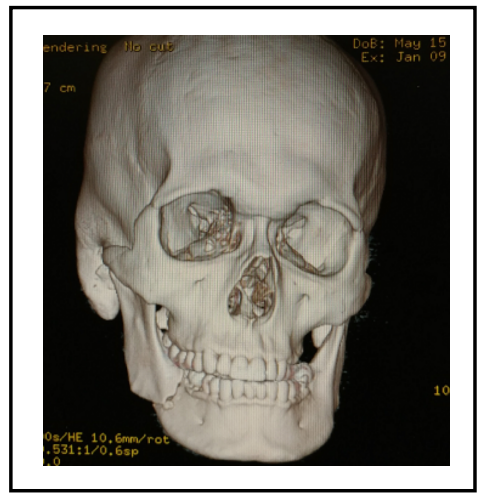

Figure 2b. 3D CT scan from anterior view with right mandible angle fracture

Disclosure: The authors have no financial interest to disclose. 


\section{INTRODUCTION}

Mandible subcondyle fracture is one of the most frequent fractures of the face. According to Lee GH, et al., subcondyle fracture is the most frequent fracture of the mandible fracture, accounted for $25-35 \%$ of the mandible fracture. ${ }^{1}$ The fracture of the mandible subcondyle is most likely due to a complex anatomical structure, where there is a rigidity in the mandible ramus whereas in the mandible subcondyle head not as rigid as mandible ramus. ${ }^{2}$ Trauma, car accident, acts of violence, falls, accidents during exercise and gunshot wounds are the most frequent external factors leading to fracture of the mandible subcondyle. Whereas, in terms of intrinsic factor, mandible fracture can be caused by osteomyelitis, tumors, and muscular spasms.

Based on the anatomical structures of the complex mandible subcondyle, effective and appropriate treatment is necessary to obtain maximum results. For decades the management of mandible subcondyle fractures has become controversial, there were many different argumentations in journals discussing management of mandible subcondyle fractures. For several years, the conservative treatment had been the main choice because it is easier and not invasive, but this treatment causes more complications, such as severe and prolonged pain, malocclusion, limitations in opening and closing the mouth, asymmetrical face, dysfunction of TMJ, and ankylosis. Because of those many complications, ORIF was considered as one of the option of management for mandible subcondyle fractures.

\section{BACKGROUND}

Based on the background, objectives, and illustrations of the cases mentioned above, a clinical question is structured: "Is ORIF a better choice than closed reduction in the treatment of mandible subcondyle fractures in terms of clinical outcomes?".

\begin{tabular}{llll}
\hline \multicolumn{1}{c}{ Patient/Problem } & \multicolumn{1}{c}{ Intervention } & Comparison & \multicolumn{1}{c}{ Outcome } \\
\hline $\begin{array}{l}\text { Patient with } \\
\text { mandible } \\
\text { subcondyle }\end{array}$ & $\begin{array}{l}\text { Management with } \\
\text { closed reduction } \\
\text { versus open } \\
\text { reduction }\end{array}$ & $\begin{array}{l}\text { Closed reduction / } \\
\text { open reduction }\end{array}$ & $\begin{array}{l}\text { Outcomes and } \\
\text { complications rate } \\
\text { in mandible } \\
\text { subcondyle } \\
\text { fracture } \\
\text { management }\end{array}$ \\
\hline Question type & Intervention & \\
Study design & Evidenced Based Case Reports & \\
\hline
\end{tabular}

Table 1. Clinical Question Formulation

\section{METHOD}

\section{Search Method}

The search was conducted on two databases, PubMed and Journal of Cranio-Maxillo-Facial Surgery (JOMS) from 23-28 January 2018. The search was conducted with the keywords mandible subcondylar fractures, open treatment, and closed treatment.
After searching with the method as above, further screening is conducted by selecting references in the last 5 years, written in English, human studies, and types of systematic review, metaanalysis, or randomized controlled trial studies. The articles search path can be seen in Figure 3 


\begin{tabular}{llc}
\hline Engines & \multicolumn{1}{c}{ Search Queries } & Results \\
\hline PubMed & (('"mandible"[MeSH Terms] OR "mandible"[All Fields] OR & 131 \\
& "mandibula"[All Fields]) AND condylar[All Fields] AND \\
& ("fractures, bone"[MeSH Terms] OR ("fractures"[All Fields] \\
& AND "bone"[All Fields]) OR "bone fractures"[All Fields] OR \\
& "fracture"[All Fields])) AND (open[All Fields] AND \\
& ("therapy"[Subheading] OR "therapy"[All Fields] OR \\
& "treatment"[All Fields] OR "therapeutics"[MeSH Terms] OR \\
& "therapeutics"[All Fields])) AND (closed[All Fields] AND \\
& ("therapy"[Subheading] OR "therapy"[All Fields] OR \\
& "treatment"[All Fields] OR "therapeutics"[MeSH Terms] OR \\
"therapeutics"[All Fields])) & \\
mandible subcondyle fracture in All Content AND open & 257 \\
treatment in All Content AND closed treatment
\end{tabular}

Table 2. Search Methods

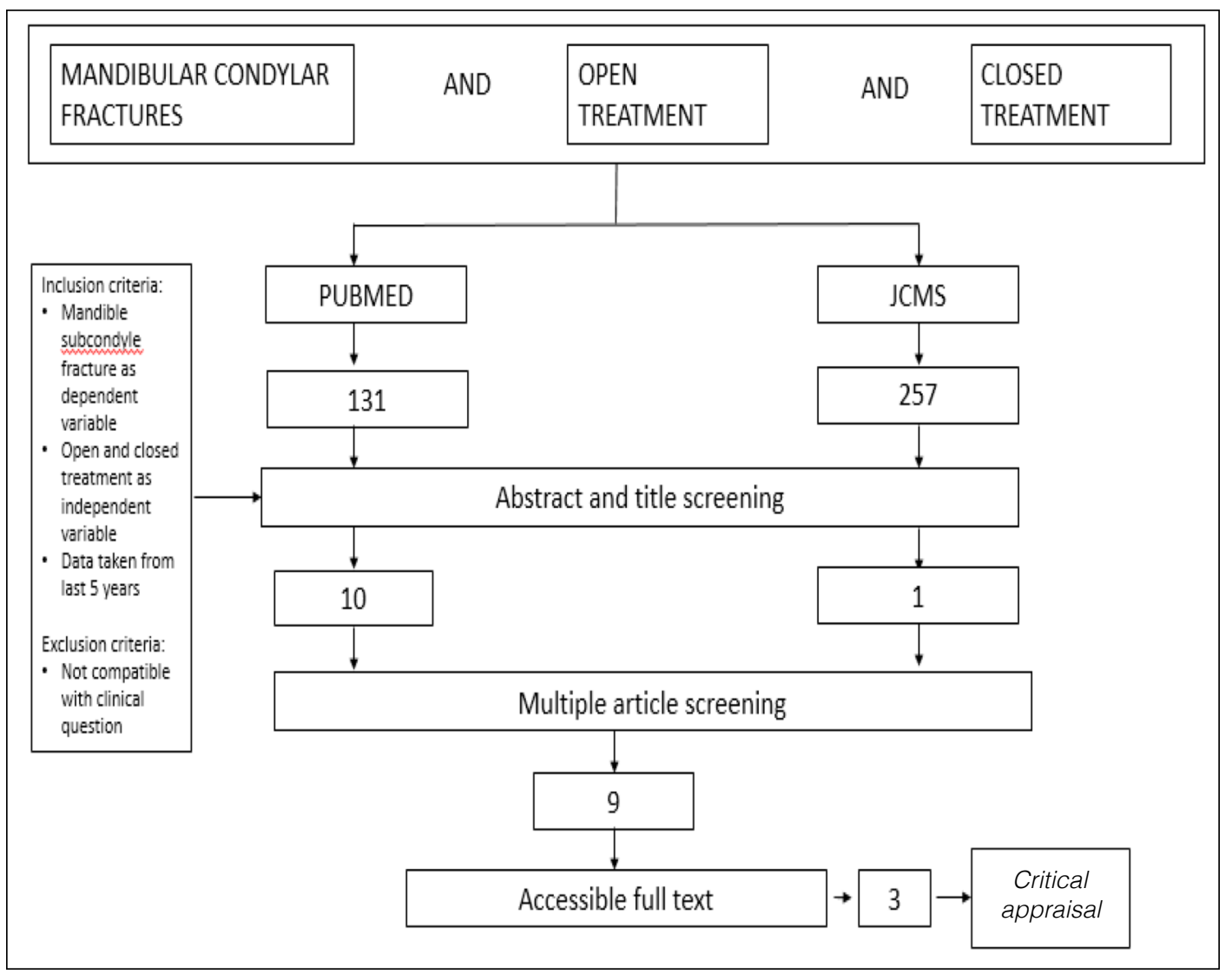

Figure 3. Article research pathway 


\section{RESULT}

From the search results on 23-28 January 2018, obtained a total of 3 articles related to this research which come from 2 databases, such as PubMed and Journal of Cranio-Maxillo-Facial Surgery (JOMS). Of the three studies, two of them were meta-analysis and one meta-analysis and systematic review. Having obtained a study with the form of meta-analysis and systematic review with a large number of samples, no further attempt to search for a randomized control trial.

\section{VALIDITY}

\begin{tabular}{|c|c|c|c|}
\hline Parameter & Berner, et al 2015 & Kyzas, et al 2012 & Al-Moraissi, et al 2015 \\
\hline $\begin{array}{l}\text { Was the } \\
\text { systematic review/ meta- } \\
\text { analysis topic compatible } \\
\text { with management topic } \\
\text { that } \\
\text { was desired? }\end{array}$ & $\begin{array}{l}\text { Yes } \\
\text { This study compared the } \\
\text { conservative management } \\
\text { with surgery to the } \\
\text { mandible subcondyle } \\
\text { fracture. } \\
\text { Including assessments of } \\
\text { malocclusion, mouth } \\
\text { opening, pain, protrusion, } \\
\text { and laterotrusion. }\end{array}$ & $\begin{array}{l}\text { Yes } \\
\text { This study evaluated the } \\
\text { obtained results } \\
\text { optimally when mandible } \\
\text { subcondyle fracture was } \\
\text { performed conservatively } \\
\text { or surgically. }\end{array}$ & $\begin{array}{c}\text { Yes } \\
\text { This study compared a } \\
\text { significant clinical } \\
\text { outcomes between } \\
\text { conservative or surgical } \\
\text { management of } \\
\text { mandible subcondyle } \\
\text { fractures in adults. }\end{array}$ \\
\hline $\begin{array}{l}\text { Was there any } \\
\text { methodology } \\
\text { that explains } \\
\text { the pathway to } \\
\text { literature searching and } \\
\text { pathway to } \\
\text { cover all } \\
\text { the relevant trial? }\end{array}$ & $\begin{array}{l}\text { Yes } \\
\text { The database used was } \\
\text { Pub Med. The author also } \\
\text { looked for unpublished } \\
\text { literature related to cases. }\end{array}$ & $\begin{array}{l}\text { Yes } \\
\text { The author looked for } \\
\text { RCT and case series from } \\
\text { the MEDLINE, EMBASE, } \\
\text { and Cochrane databases } \\
\text { (last August 2010). The } \\
\text { author also used database } \\
\text { from maxillofacial } \\
\text { surgery books } \\
\text { (Booth et al., 2017) and } \\
\text { related expertise for } \\
\text { additional studies that } \\
\text { may be included. }\end{array}$ & 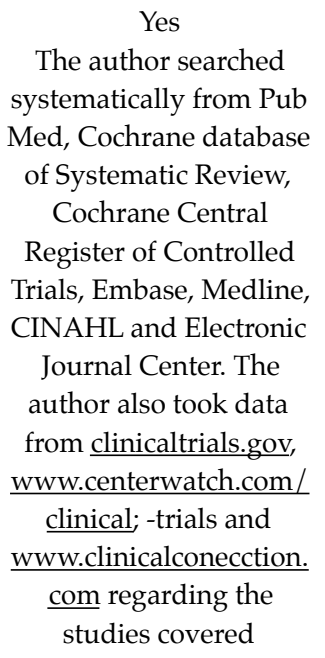 \\
\hline $\begin{array}{l}\text { Were each study assessed } \\
\text { for its validity? }\end{array}$ & $\begin{array}{l}\text { Yes } \\
\text { The authors reviewed the } \\
\text { articles independently in } \\
\text { the form of a retrospective } \\
\text { or prospective study that } \\
\text { had inclusion criteria, and } \\
\text { meta-analysis that had } \\
\text { standardized statistical } \\
\text { data }\end{array}$ & $\begin{array}{c}\text { Yes } \\
\text { The author reviewed all } \\
\text { titles and abstracts } \\
\text { independently of all } \\
\text { RCTs and case series } \\
\text { required that bound } \\
\text { within the inclusion } \\
\text { criteria. If there was a } \\
\text { discrepancy of } \\
\text { information in the article, } \\
\text { it would be solved by a } \\
\text { discussion involving a } \\
\text { third author }\end{array}$ & $\begin{array}{l}\text { Yes } \\
\text { The authors } \\
\text { independently reviewed } \\
\text { all the titles and } \\
\text { abstracts of all RCTs, } \\
\text { CCTs, and retrospective } \\
\text { studies whose validity of } \\
\text { each study was } \\
\text { measured by MOOSE, } \\
\text { STROBE, and PRISMA } \\
\text { to reduce the bias in the } \\
\text { data. }\end{array}$ \\
\hline $\begin{array}{l}\text { Were the results } \\
\text { consistent from one } \\
\text { study to another? }\end{array}$ & Yes & $\begin{array}{l}\text { No } \\
\text { The results obtained } \\
\text { quite diverse because of } \\
\text { limitation in data quality. }\end{array}$ & Yes \\
\hline
\end{tabular}




\section{IMPORTANCE}

\begin{tabular}{|c|c|c|c|}
\hline Parameter & Berner, et al 2015 & Kyzas, et al 2012 & Al-Moraissi, et al 2015 \\
\hline $\begin{array}{l}\text { What was the } \\
\text { overall result? }\end{array}$ & $\begin{array}{l}\text { There was a significant } \\
\text { difference in lateralotrusion } \\
\text { pain and protrusion pain } \\
\text { reduction in open } \\
\text { reduction and internal } \\
\text { fixation in the area of the } \\
\text { subcondyle fracture. } \\
\text { However, in the movement } \\
\text { of the mouth and occlusion } \\
\text { there was no significant } \\
\text { difference. The } \\
\text { complication on ORIF was } \\
\text { a wound on the face and } \\
\text { facial nerve weakness. }\end{array}$ & $\begin{array}{l}\text { Meta-analysis showed that } \\
\text { ORIF was better or as good } \\
\text { as closed management in } \\
\text { some cases in terms of } \\
\text { morbidity, occlusion, oral } \\
\text { movement, ankylosis, } \\
\text { protrusion, facial } \\
\text { symmetry, pain and } \\
\text { overall function). } \\
\text { However, in ORIF there } \\
\text { were complications of } \\
\text { weakness in the facial } \\
\text { nerve (6.6\%), but would } \\
\text { disappear by itself less } \\
\text { than } 6 \text { months, while the } \\
\text { persistent facial nerve } \\
\text { deficiency was less than } \\
1 \%\end{array}$ & $\begin{array}{c}\text { From the results of the meta- } \\
\text { analysis there were significant } \\
\text { differences from postoperative } \\
\text { ORIF and closed management } \\
\text { results, seen from } \\
\text { lateralotrusion, occlusion and } \\
\text { chin deviation. The results of the } \\
\text { study also explained that pain in } \\
\text { ORIF was more tolerable than } \\
\text { Closed Reduction (VAS 6). } \\
\text { Complication in ORIF showed } \\
\text { scarring and weakness in nerve } \\
\text { VII (about 0-21\%) but was } \\
\text { temporary (disappear in less } \\
\text { than } 6 \text { months). Only about } \\
5.83 \% \text { of patients was re- } \\
\text { operated due to facial nerve } \\
\text { deficiency. }\end{array}$ \\
\hline
\end{tabular}

\section{APLICABILITY}

\begin{tabular}{|c|c|c|c|}
\hline Parameter & Berner, et al 2015 & Kyzas, et al 2012 & Al-Moraissi, et al 2015 \\
\hline $\begin{array}{l}\text { Could these } \\
\text { results be } \\
\text { applied to } \\
\text { patient care? }\end{array}$ & $\begin{array}{l}\text { Yes } \\
\text { The subjects of the study } \\
\text { were patients with } \\
\text { mandible subcondyle } \\
\text { fractures. }\end{array}$ & $\begin{array}{l}\text { Yes } \\
\text { The subjects of this meta- } \\
\text { analysis study consisted of } \\
\text { different ages and different } \\
\text { regions of the mandible } \\
\text { subcondyle fractures } \\
\text { unilaterally or bilaterally }\end{array}$ & $\begin{array}{l}\text { Yes } \\
\text { Patients of mandible (unilateral } \\
\text { or bilateral) subcondyle } \\
\text { fractures of various ages and } \\
\text { followed up for about } 6 \text { months } \\
\text { to } 3 \text { years. }\end{array}$ \\
\hline $\begin{array}{l}\text { Were all } \\
\text { important } \\
\text { clinical } \\
\text { outcomes } \\
\text { considered? }\end{array}$ & $\begin{array}{l}\text { Yes } \\
\text { The outcomes that were } \\
\text { mainly taken into account } \\
\text { in this study were } \\
\text { movement of the mouth, } \\
\text { protrusion, laterotrusion, } \\
\text { pain and occlusion after } \\
\text { management }\end{array}$ & $\begin{array}{l}\text { Yes } \\
\text { the outcomes that are } \\
\text { mainly taken into account } \\
\text { in this study were the } \\
\text { advantages and } \\
\text { disadvantages after the } \\
\text { management (movement } \\
\text { of the mouth, protrusion, } \\
\text { laterotrusion, pain, warp, } \\
\text { TMJ function, scarring and } \\
\text { facial nerve weakness) }\end{array}$ & $\begin{array}{l}\text { Yes } \\
\text { Overall, the calculated outcome } \\
\text { was from objective and } \\
\text { subjective perspective }\end{array}$ \\
\hline $\begin{array}{l}\text { Were the } \\
\text { benefits of the } \\
\text { management } \\
\text { more than the } \\
\text { disadvantage? }\end{array}$ & $\begin{array}{c}\text { Yes } \\
\text { Results of ORIF were better } \\
\text { than CT results. } \\
\text { Complications arise on } \\
\text { ORIF could still be } \\
\text { tolerated }\end{array}$ & $\begin{array}{l}\text { Yes } \\
\text { ORIF gave better results } \\
\text { than CT, with temporary } \\
\text { disadvantages and } \\
\text { complication that } \\
\text { acceptable }\end{array}$ & $\begin{array}{l}\text { Yes } \\
\text { The ORIF results were more } \\
\text { significant than CT with } \\
\text { acceptable facial injury and } \\
\text { temporary facial VII facial } \\
\text { weakness }\end{array}$ \\
\hline
\end{tabular}

Table 3. Critical Appraisal of Articles Obtained 


\section{DISCUSSION}

Of all fractures that occur in facial region, mandible fracture is the most frequent fracture after nasal fracture and zygoma fracture. Fracture of condylar neck and subcondylar fracture are frequent mandible fractures. These fractures are most often caused by trauma, falls, exercise and accidents. ${ }^{3}$ The mandible has a thick cortical layer of compact bone that is reinforced on its interior border so that the torque, i.e the occlusal forces exerted by dentition, may be accommodated. the alveolar sockets are surrounded by the spongiosum and the dental forces are transferred via the periodontal ligament to the alveolar bone and from there to the nasal bone. The forces released through the dentition are further transmitted through the bone trabeculae, then the compact bone, and they eventually become concentrated at the condyle head. From here, the force spreads to the squamous part of the temporal bone for distribution over the skull base. This anatomical construction of the mandible and its relation to the mid face and skull base will result in a fracture occurring in the region of the force of impact, and usually also at the area of weakness lying in vector of the fore (a contrecoup fracture). Therefore, in the overall majority cases, mandible trauma will present with two or more fractures (Figure 4.) ${ }^{4}$

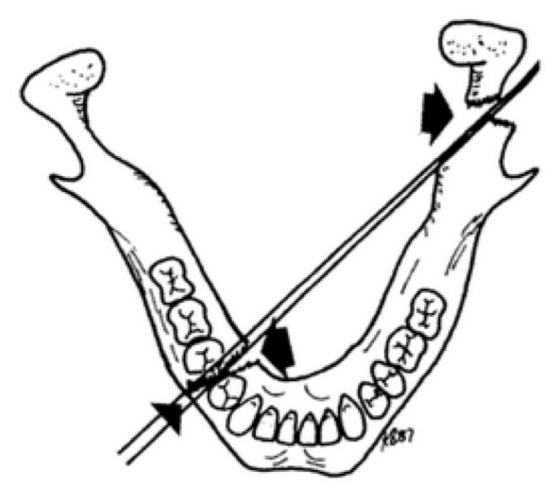

Figure 4. A direct (simpe, orpus) and a contrecoup (condylar neck) fracture in line of the vector

Management of mandible subcondyle fractures can be done either conservatively (closed reduction) or by ORIF. For several years, surgeons used the conservative method but judging from the complications that occurred after the closed reduction, ORIF is developed as a treatment that demonstrate more satisfying results, although it is unclear whether there is a significant difference in outcomes in conservative or ORIF.

Zide and Kent's divide two indications for open reduction. First, absolute indication, such as displacement into middle cranial fossa, impossibility of obtaining adequate occlusion by closed reduction, lateral extracapsular displacement, invasion by foreign body. Second, for relative indication, such as bilateral condylar fractures in an edentulous patient without a splint, unilateral or bilateral condylar fractures where splinting cannot be accomplished for medical reasons or because physiotherapy is impossible, bilateral condylar fractures with comminuted midfacial fractures, prognathia or retrognathia, periodontal problems, loss of teeth, unilateral condylar fracture with unstable base. ${ }^{5}$.

According to the results of the these studies (2 meta-analyzes and 1 meta-analysis and systematic review) comparing results of ORIF management with conservative management based on malocclusion, protrusion, laterotrusion, pain, mouth movement and symmetry of face, ORIF objectively and subjectively provides more satisfying results rather than conservative treatment, although ORIF has the complication of cicatrix and temporary facial weakness.

The three literatures are the latest literatures in the last 5 years about the comparison between ORIF and closed reduction on subcondylar mandibular fracture. Berner, et al. discusses the results of ORIF and CT. The other studies (Kyzas, et al and AlMoraissi, et al) discusses about the comparative results of ORIF and CT and complications in patients with ORIF treatment, although, according to Kyzas, et al. the data obtained has not been consistent due to data limitations, so there is still a need for further research, especially prospective study. Based on those literatures, they conclude that ORIF is a better choice than closed reduction due to clinical outcomes.

Berner, et al. study's followed up the subcondyle movement on one side after 6 weeks, 6 months, 1 , 2,3 years postoperatively, the results obtained were in the open and close mouth motion $(\mathrm{MD}=$ $2.12,95 \% \mathrm{CI}=-0.68$ to $4.93, \mathrm{p}=\mathrm{s} 0.14$ ) the results were not significantly different in ORIF and CT. 
Evaluation on the protrusion was obtained (MD = $1.12,95 \% \mathrm{CI}=0.42-1.82, \mathrm{p}=0.0016)$, there were significant difference, the laterotrusion result was $(\mathrm{MD}=2.36,95 \% \mathrm{CI}=1.78-2.93, \mathrm{p}=0.0001)$. Significant result occurs between ORIF and CT management. Singh et al. (2010) evaluated occlusion disorders in patients 6 months postoperatively, the results was there is no significant difference $(\mathrm{p}=0.86)$. Haug and Assael (2001) used the scale "same like before trauma" with a value of 1 to "great malocclusion" with a value of 5 , the results obtained also has no significant difference.

According to Kyzas et al, ORIF may be better or as good as CT in treating mandible subcondyle fracture, seen from four RCTs and 26 case series. From this study it is found that ORIF is causing facial nerve weakness $(6.6 \%)$ but disappeared in less than six months, required minor surgery and less than $1 \%$ had irreversible facial nerve defects. From RCTs, it is obtained more occlusion problems on $\mathrm{CT}$ than ORIF. Postoperative lesions can also be tolerated in patients, although there is no objective evidence.

Overall, Al-Moraissi et al, states that ORIF gave better results in terms of overall aspects, particularly subcondyle and mandible motion compared with CT. In this study we found that MIO (Maximal Interincisal Opening) showed better results after ORIF than CT (WMD, $3.23 \mathrm{~mm}$; 95\% CI, $2.42-4.04 \mathrm{~mm}$; $=.001)$. Similar to laterotrusion, in the ORIF patients the results obtained are much better, indicating better movement of the subcondyle (WMD, $1.14 \mathrm{~mm}$, 95\% CI, $0.73-1.55 \mathrm{~mm}$; $=.001)$. In ORIF, the protrusion is also better than CT (WMD, $0.99 \mathrm{~mm}$; 95\% CI, 0.70 - $1.29 \mathrm{~mm}$; $\mathrm{P}=.001)$. ORIF also decreases the incidence of chin movements by $38 \%$ when compared with CT. The study also showed that occlusion disorders were less common in ORIF patients (OR, $0.41 \mathrm{~mm}, 95 \% \mathrm{CI}, 0.26$ to 0.62 $\mathrm{mm}, \mathrm{P}=.001)$. Assessment of pain in six months after surgery assessed with VAS resulted that ORIF was better than CT, coupled with pain in TMJ was also reduced. The facial weakness on ORIF is $5.83 \%$ but it disappears less than six months. Post lesions cannot be documented actually because of the limited data, but from subjective assessment, postoperative wounds can be tolerated.
The results of the three studies suggest that ORIF provides a superior outcome than closed reduction, although ORIF has disadvantages that results in the cicatrix on the face, but overall the wound is still tolerable by the patient. In addition to facial injuries, ORIF also weakens the nerves of the face, especially the VII nerve, but this weakness will recover by itself in less than six months, a few patients experience irreversible neurological weakness, and only a few or almost no patients require recurrent surgery.

All subjects in all three of these studies were patients diagnosed with mandible subcondyle fractures, unilaterally or bilaterally, from all age ranges and from any etiology, and obtained similar results with the results of the overall study of group analysis. The results of the entire study can be applied to patients in case illustrations.

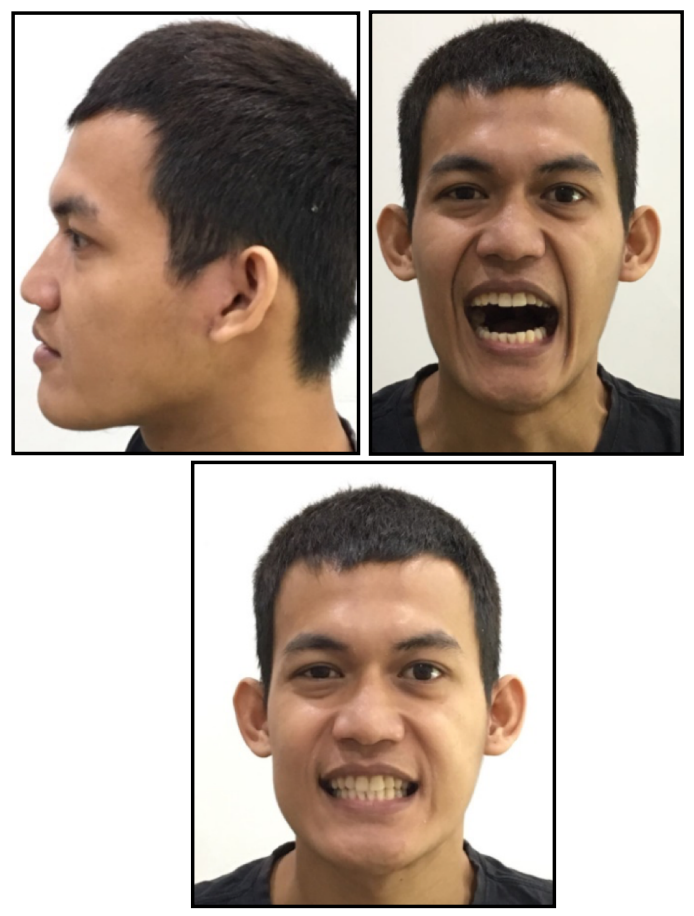

Figure 5. two months after operation, swelling has gone and mouth can close completely without facial nerve paralysis. 


\section{CONCLUSION}

Based on the critical appraisal of the three literatures obtained, it can be concluded that ORIF provides a more satisfactory outcomes postoperatively and several months after surgery, than closed reduction. Although ORIF results in cicatrix on the face and had complication such as temporary weakness of facial nerve, only small repeated surgery needed.

\section{SUGGESTION}

To obtain stronger evidence, further costeffective studies comparing the open and closed reduction methods may be required.

\section{Corresponding author:}

Kristaninta Bangun

kristaninta@yahoo.com

\section{REFERENCES}

1. Lee $\mathrm{GH}$, et al. Retromandibular Reduction of Medially Dislocated Condylar Process Fractures. Archieves of Plastic Surgery. 2018; 45:23-28.

2. Choi KY, et al. Current Concepts in the Mandibular Condyle Fracture Management Part I : Overview of Condylar Fracture. Archieves of Plastic Surgery. 2012; 39:291-300.

3. Shirani G, et al. A New Method for Surgical Treatment of Subcondylar Fractures : A Case Report. Journal of Dentistry. 2017; Vol. 14, No.5.

4. Mieny, C.J and Mennen, U. Principles of Surgical Patient Care. $2^{\text {nd }}$ ed. New Africa Education. 2003.

5. Spinzia A, et al. Open reduction and internal fixation of extracapsular mandibular condyle fractures: a long-term clinical and radiological follow-up of 25 patients.

6. Berner T, et al. Closed Versus Open reduction of Mandibular Condylar Process Fractures : a metaanalysis of Retrospective and Prospective Studies. Journal of Cranio-Maxillo-Facial-Surgery. 2015.

7. Kyzas PA, et al. The Treatment of Mandibular Condyle Fractures :A Meta-Analysis. Journal of Cranio-Maxillo-Facial-Surger.2012 ; 438-452.

8. Al-Moraissi EA, et al. Surgical Treatments of Adult Mandibular Condylar Fractures Provides Better Outcomes than Closed reduction : A Systematic Review and Meta-Analysis. Journal of CranioMaxillo-Facial-Surgery. 2015; 73:482-493. 